\title{
Kultur Jaringan Jeruk Keprok Tejakula (Citrus reticulata var. Tejakula) Menggunakan Tunas Muda dan Biji Serta Deteksi CVPD dengan Teknik Polymerase Chain Reaction (PCR)
}

\author{
VLORA VERONICA SIPANGKAR, I NYOMAN WIJAYA*), DAN \\ MADE SRITAMIN
}

Program Studi Agroekoteknologi, Fakultas Pertanian, Universitas Udayana J1. PB. Sudirman, Denpasar 80231 Bali

${ }^{*}$ E-mail: wijayainyoman1956@gmail.com

\begin{abstract}
Tissue Culture Citrus (Citrus reticulata var. Tejakula) using Shoot and Seed and the Detection of CVPD with Polymerase Chain Reaction (PCR). The sample was taken in Pecatu Village, Kuta Selatan District, Badung Regency and continued with in vitro culture and PCR analysis at UPT. Genetic Resource and Molecular Biology Laboratory, was start from December of 2018 until May of 2019. The purpose of this research was to create a CVPD free Citrus reticulata var. Tejakula seedling from tissue culture. The sample was chosen based on visual characteristic. Two samples were taken from citrus plant that show CVPD symptoms and citrus plant that did not show CVPD symptoms. The seed and shoot were cultured using MS media for 12 week after planting (WAP). From this research showed that both explant from the shoot and seed were able to grow well. The explant from citrus sample that showed CVPD symptoms was infected by Liberibacter asiaticus and the explants from citrus that did not show CVPD symptoms was not invected by Liberibacter asiaticus, according to PCR analysis.
\end{abstract}

Keywords: citrus, bacterium Liberibacter asiaticus, CVPD disease, tissue culture, seed, shoot

\section{PENDAHULUAN}

Jeruk (Citrus sp.) merupakan salah satu komoditas buah-buahan yang digemari oleh masyarakat Indonesia. Buah jeruk memiliki nilai gizi yang cukup tinggi. Diantaranya adalah vitamin $\mathrm{C}$, antioksi dan dan kalium (Widyadkk., 2016). Jeruk keprok Tejakula (Citrus reticulata) merupakan jeruk yang di budidayakan di Bali khususnya di Bali Utara. Jeruk ini berkembang di sekitar pantai di Kecamatan Tejakula, Kabupaten Buleleng, Bali.

Pada tahun 1995 terdapat jeruk keprok Tejakula yang terserang CVPD 40-60\% di kawasan Bali Utara (Dwiastutidkk., 2003). Serangan CVPD ini masih berdampak hingga 
VLORA VERONICA SIPANGKAR. et al. Kultur Jaringan Jeruk Keprok Tejakula...

sekarang yang mengakibatkan produksi jeruk keprok Tejakula sangat menurun.

Penyakit CVPD sering disebut juga huanglongbin (HLB) disebabkan oleh Liberibacterasiaticus (Jaqoueixet al., 1996) termasuk bakteri gram negatif (Garnier et al., 1984) dan dapat ditularkan oleh serangga vector Diaphorinacitri. Upaya pengendalian penyakit CVPD adalah dengan mengenali gejala sejak dini dan penggunaan bibit bebas patogen. Penyakit CVPD dapat dikenali dengan ciri-ciri klorosis atau daunnya menguning, warna tulang daunnya menjadi hijau tua, daunnya lebih tebal, kaku dan ukuran buahnya menjadi kecilkecil serta kulit buah cepat menguning (Wijaya, 2003).

Peningkatan ketersediaan benih jeruk dengan kualitas tinggi dapat dilakukan dengan menggunakan teknologi kultur jaringan (Vida, 2018). Kutur jaringan tanaman adalah suatu teknik untuk menumbuh kansel, jaringan dan organ tanaman di laboratorium pada suatu media buatan yang mengandung nutrisi yang aseptic (steril) untuk menjadi tanaman secara utuh (Dwiyani, 2015). Kelebihan kultur jaringan yaitu dapat menghasilkan tanaman yang lebih banyak jika dibandingkan dengan pembibitan secara langsung dan dengan waktu yang relative singkat (Bhojiwani, 1983).

\section{BAHAN DAN METODE}

\section{Tempat dan Waktu Penelitian}

Penelitian dilaksanakan di Laboratorium Analisis Sumber daya Genetika dan Molekuler Universitas Udayana. Pengambilan sampel dilakukan di Desa Pecatu, Kecamatan Kuta Selatan, Kabupaten Badung. Penelitian ini dilakukan sejak Desember 2018 sampai Mei 2019.

\section{Alat dan Bahan}

Alat yang digunakan dalam penelitian ini terdiri atas timbangan digital, magnetic stirrer, autoclave, microwave/oven, Laminar Air Flow Cabinet, inkubator, mesin vortex, water bath, pestle, PCR tube, transiluminator UV, mesin elektroforesis, PCR, kertas parafilm, spatula, kertas label, kamera digital, gelas ukur, backer glas, gelas labu erlemenyer, botol kultur, pinset, gunting, gcalpel, mortar, micropipet, tissue, apibunsen, cawan petri, centrifuge, sprayer dan eppendort (tabungmikro).

Bahan yang digunakan dalam penelitian ini terdiri atas eksplanya itu biji dan tunas jeruk keprok Tejakula yang terserang CVPD dan yang tidak terserang CVPD, Aquades, MS (Murashige and Skoog ), Gellan gum, Sucrose, B5 Vitamin Stock (Myo- Inositol, Thiamin- HCL, Nicotine Acid, Pyridoxine-HCL), Detergen, Benlite, 
Alkohol 70\%, Natrium Hipoklorit, Tween, Agarose, TAE 100 ml, Genom DNA Mini Kit Plant, PCR Master Mix Solution, Marker DNA $1 \mathrm{~kb}$ Ladder, Loading Dye, Etidium Bromida, Liquid Nitrogen, dan sepasang Primer Spesifik untuk mendeteksi keberadaan bakteri Liberobacterasiaticus.

\section{Pelaksanaan Penelitian}

Pengambilan Sampel Tanamanm Jeruk

\section{Keprok Tejakula}

Penelitian ini dimulai dengan pengambilan eksplan daun, tunas dan buah jeruk keprok Tejakula di Desa Pecatu, Kecamatan Kuta Selatan, Kabupaten Badung. Penentuan tanaman yang akan digunakan pada penelitian ini dilihat berdasarkan visual yang ditunjukkan oleh tanaman yang bergejala penyakit CVPD dan tidak bergejala CVPD. Bagian tulang daun jeruk Keprok Tejakula digunakan pada tahap PCR yang pertama untuk menentukan secara pasti apakah tanaman yang diambil terinfeksi oleh bakteri Liberobacterasiaticus atau tidak terinfeksi dan bagian yang tidak terinfeksi digunakan sebagai bahan eksplan yang akan ditanam pada media kultur secara In vitro.

\section{Sterilisasi Alat dan Bahan}

Botol kultur, pinset dan cawan petri yang akan digunakan dicuci dengan bersih menggunakan detergen. Kemudian dikeringkan. Setelah keringcawan petri dibungkus rapi menggunakan kertas, pinset, skapel dibungkus menggunakan alumunium foil, kemudian di autoclave selama 15 menit dengan suhu $121^{\circ} \mathrm{C}$.

\section{Sterilisasi Ruang Inokulum}

Ruang inoculum dan Laminar Air Flow yang akan digunakan dibersihkan terlebih dahulu dengan menyemprotkan alkohol 70\% keseluruh dinding dan alasnya kemudian Laminar Air Flow dikeringkan menggunakan tissue, kemudian lampu ultraviolet yang ada didalamnya di hidupkan dan di diamkan selama 30-60 menit yang bertujuan untuk membunuh kontaminan yang berada di Laminar Air Flow.

\section{Pembuatan Media}

Media adalah factor penentu dalam perbanyakan dengan kultur jaringan. Media eksplan terdiri dari berbagai macam campuran bahanya kniunsur mineral baik mikronutrient dan makronutrient, Zat Pengatur Tumbuh, Senyawa organik, vitamin dan asam Amino. Media yang digunakan adalah MS. Untuk $100 \mathrm{ml}$ stock MS 
VLORA VERONICA SIPANGKAR. et al. Kultur Jaringan Jeruk Keprok Tejakula...

dibutuhkan sukrosa $3 \mathrm{~g}$, Gellum gum 0,4 g, dan $1 \mathrm{ml}$ vitamin. Stock vitamin yang digunakan terdiri dari $(100 \mathrm{mg} / \mathrm{ml}$ Myoinositol, $10 \mathrm{mg} / \mathrm{ml}$ Thiamine- HCL, $1 \mathrm{mg} / \mathrm{ml}$ Nicotinic acid, $1 \mathrm{mg} / \mathrm{ml}$ Pyridoxine- HCL). Untuk $100 \mathrm{ml}$ MS ditambahkan BAP dan NAA masing-masing $1 \mathrm{ml}$ sehingga terdapat media yang terdiri dari MS+BAP dan media MS+BAP+NAA. Setelah semua bahannya digabungkan kemudian diaduk menggunakan magnetic stirrer hingga semua bahan homogen, setelah itu di panaskan di microwave selama 5 menit dan di tuangkan kedalam botol kultur.

\section{Sterilisasi Eksplan}

Biji dikupaster lebih dahulu untuk mengurangi lendirnya dan tunas dipotong menjadi bagian kecil, kemudian dicuci dengan air mengalir selama 15 menit lalu dicuci menggunakan detergen hingga lendirnya hilang. Eksplan direndam dalam benlate 0,2 gr/100 ml selama 10 menit, kemudian dicuci menggunakan alkohol $70 \%$ selama 2 menit. Setelah itu direndam dalam larutan Natrium Hipoklorit 20\% dengan penambahan 2 tetes tween minimal 5 menit dan terakhir dibilas menggunakan aquade sehingga bersih.

\section{Penanaman Eksplan}

Sumber eksplan adalah biji dan tunas tanaman jeruk keprok Tejakula. Penanaman dilakukan di Laminar Air Flow yang telah disterilkan. Eksplan steril dimasukkan ke dalam cawan petri, kemudian tunas di potong setiap ujungnya untuk mengatasi terjadinya browning. Ekplan di tanam pada media yang telah disiapkan, setelah ditanam botol kultur direkat dengan plastic wraping, selanjutnya di simpandi rak kultur. Inkubasi kultur dilakukan di dalam ruangan dengan suhu $20-28^{\circ} \mathrm{C}$.

\section{Deteksi Penyakit CVPD dengan Teknik PCR}

Deteksi penyakit CVPD dilakukan setelah ekpslan tumbuh menjadi tanaman dari hasil kultur jaringan. Bagian tanaman yang diambil adalah seluruh bagian tanaman. Kemudian dilakukan isolasi DNA total dan deteksi CVPD dengan PCR.

Isolasi DNA total dilakukan dengan Genomic DNA Mini Kit Plant. Sampel daun jeruk dipotong kemudian digerus sampai halus menggunakan mortar sambil di tambah liquid nitrogen dan di taruh dalam ependorf. Disus pensi dalam lysys buffer $400 \mu$ GPL dan ditambahkan $5 \mu$ l RNase A dan divortex agar bahannya homogen. Hasil dari suspense tadi di taruh dalam tabung mikro $1,5 \mathrm{ml}$ dan di inkubasi pada suhu $60^{\circ} \mathrm{C}$ selama 10 menit 
dengan membolak balikkan ependorf selama 5 menit sekali, setelah selesai ditambahkan 100 $\mu 1$ GP2 Buffer dan vortex, kemudian di inkubasi pada es selama 3 menit (pada saatitu juga elution buffer di inkubasi pada suhu $60^{\circ} \mathrm{C}$ yang selanjutnya digunakan pada tahap akhir isolasi DNA) Tempatkan filter column pada collection tube kemudian pindahkan suspense ekstrak tanaman pada filter column dan sentrifuge selama 1 menit pada $1.000 \mathrm{xg}$. Supernatan yang di hasilkan di pindahkan pada collection tube yang baru dan ditambahkan $750 \mu$ l GP3 Buffer kemudian di tempatkan pada GD column, selanjutnya di sentrifuge pada $14.000-16.000 \mathrm{xg}$ selama 30 detik. Cairannya dibuang dan ditaruh pada GD column pada b2 $\mathrm{ml}$ collection tube, tambahkan $600 \mu \mathrm{l}$ wash buffer pada GD column kemudian sentrifuge 14.000-16.000 xg selama 30 detik, dibuang cairannya dan GD column di tempatkan $2 \mathrm{ml}$ collection tube kemudian di sentrifuge lagi untuk mengeringkan GD column. Pindahkan GD column yang sudah kering kemikro sentrifuge tube lalu tambahkan $100 \mu l$ preheated TE buffer atau elution buffer di tengah-tengah GD column lalu di diamkan 3-5 menit, lalu sentrifuge 14.000-16.000 xg selama 30 detik. DNA tersisa pada eppendorf tube merupakan DNA tanaman yang akan di gunakan untuk mengetahui hasil isolasi DNA.

\section{Amplifikasi DNA}

Analisis teknik PCR untuk mendeteksi keberadaan bakteri Liberibacterasiaticus pada tanaman di lakukan dengan menggunakan primer spesifik dari 16r DNA, Forward primer O11 (5' GCG CGT ATG CAA TAC GAG GGG C 3') dan Reverse primer O12c (5' GCC TCG CGA CTT CGC AAC CCAT 3'). DNA hasil isolasi di amplifikasi sebanyak $20 \mu$ dengan teknik PCR. Reaksi PCR terdiri dari $2 \mu \mathrm{l}$ DNA sampel, $1 \mu 1$ Forward primer dan $1 \mu 1$ Reverse primer, $10 \mu 1$ PCR Master Mix Solution dan 6 $\mu 1$ buffer TE.

\section{Elektroforesis dan Visualisasi Hasil PCR}

Fragmen DNA hasil amplifikasi PCR di elektroforesis pada gel Agarose 1\%, penyangga untuk elektroforesis digunakan TAE $1 \%$ yang mengandung $40 \mathrm{mM}$ sodium EDTA. Elektroforesis dilakukan pada 100 voltselama 1 jam. Selanjtnya dilihat dengan Transilu minator UV.

\section{HASIL DAN PEMBAHASAN}

Hasil pengamatan secara visual pada areal pertanaman jeruk Keprok Tejakula di desa Pecatu, Kecamatan Kuta Selatan, Kabupaten Badung. Terdapat dua sampel jeruk yaitu, tanaman jeruk yang mengalami gejala CVPD dan tanaman jeruk yang tidak bergejala CVPD. 


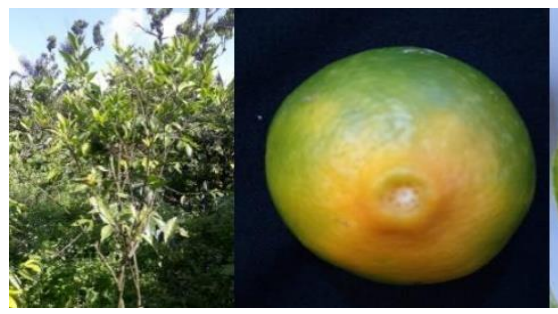

A
B



$\mathrm{C}$

Gambar 1. Sampel tanaman jeruk keprok Tejakula bergejala penyakit CVPD Tanaman keseluruhan (A), buah bergejala (B), daun bergejala ( C )



A B $\mathrm{C}$

Gambar 2. Sampel tanaman jeruk keprok Tejakula yang tidak bergejala penyakit CVPD Tanaman keseluruhan (A). Daun sehat/ tidak bergejala ( B ). Buah sehat/ tidak bergejala (C)

Pengamatan 3 Minggu Setelah Tanam pertumbuhan yaitu, muncul kotiledon, (mst) eksplan biji mengalami perubahan sedangkan tunas muda muncul daun kecil.

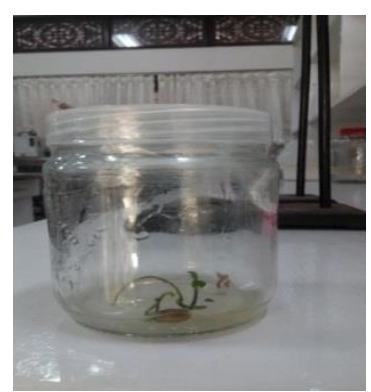

A

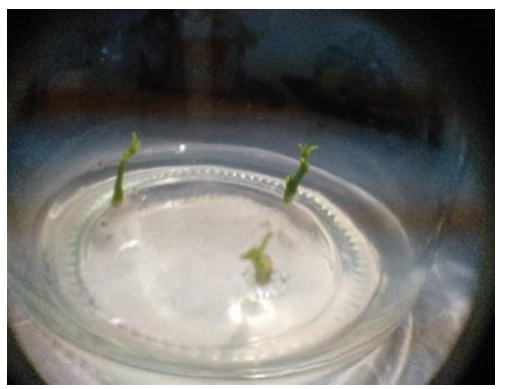

B

Gambar 3. Kultur In Vitro biji dan tunas muda jeruk keprok Tejakula. (A) kultur biji 4 mst (B) kultur tunas muda 4 mst. 
Pengamatan selanjutnya pada 8 mst ditemukan oleh Antoni Van Leeuwenhoek eksplan biji tumbuh dua daun pertama, batang pada tahun 1719 pada biji jeruk. Bentuk biji dan akar. Sedangkan pada tunas muda muncul mempengaruhi sifat poliembrioni biji jeruk daun, tunas dan kalus. Pengamatan pada 8 mst yaitu biji yang berbentuk bulat dan berbentuk pada biji di temukan munculnya sifat bulat telur dapat menghasilkan dua hingga tiga poliembrioni biji tanaman. Poliembrioni semaian di dalam satu biji (Awuy, 1993).

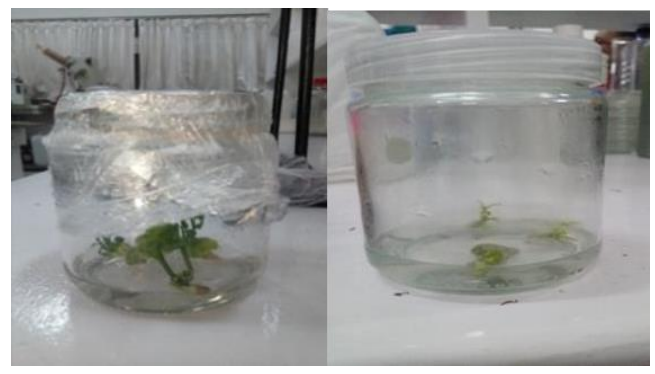

A

B

Gambar 4. Kultur In Vitro biji dan tunas muda jeruk keprok Tejakula. (A) kultur biji 8mst (B) kultur tunas muda 4 mst.

Pengamatan selanjutnya 12 mst, akar, batang dan daun sedangkan tunas muda, eksplan biji dan tunas muda jeruk keprok pada sudah terdiri dari batang dan daun. sudah terbentuk tanaman, biji sudah tumbuh

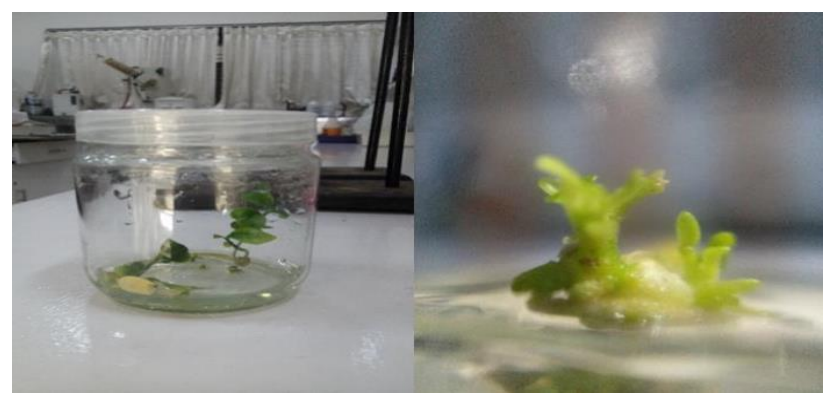

A

B

Gambar 5. Kultur In Vitro biji dan tunas muda jeruk keprok Tejakula, (A) kultur biji 12 mst, (B) kultur tunas muda 12 mst. 
VLORA VERONICA SIPANGKAR. et al. Kultur Jaringan Jeruk Keprok Tejakula...

Hasil dari DNA total yang telah di menunjukkan bahwa semua sampel jeruk elektroforesis dengan gel agarose $1 \%$ dan di memiliki DNA.

amati menggunakan transilluminator UV

\section{4}



Gambar 6. Hasil elektroforesis DNA total Tanaman jeruk setelah dikultur dengan gel agarose 1\%. (1) DNA biji tidak bergejala di lapangan (2) DNA tunas tidak bergejala di lapangan (3) DNA biji bergejala di lapangan (4) DNA tunas bergejala di lapangan

Terdapat pita DNA hasilisolasi DNA DNA antara 1.000-1500 bp, Jagoueixat al., total semua sampel tanaman jeruk yang 1996 menyatakan bahwa bakteri bergejala CVPD dan yang tidak bergejala Liberobacterasiaticus teramplifikasi pada CVPD, Amplifikasi dengan teknik PCR 1160 bp, halini menyatakan bahwa sampel membutuhkan kualitas DNA yang bagus dan yang bergejala CVPD di lapangan, setelah di program yang sesuai (Taylor, 1993). kultur hasilnya tetap mengandung bakteri

Hasil elektroforesis pada gambar 6 Liberobacterasiaticus. Sedangkan sampel 3 menunjukkan bahwa sampel 1 dan 2 dan 4 merupakan jeruk yang tidak bergejala merupakan jeruk yang bergejala CVPD di CVPD di lapangan yang diamati secara visual lapangan yang di amati secara visual setelah di tidak menunjukkan adanya pita DNA pada kultur secara In vitro menunjukkan adanya pita 1160 bp. 


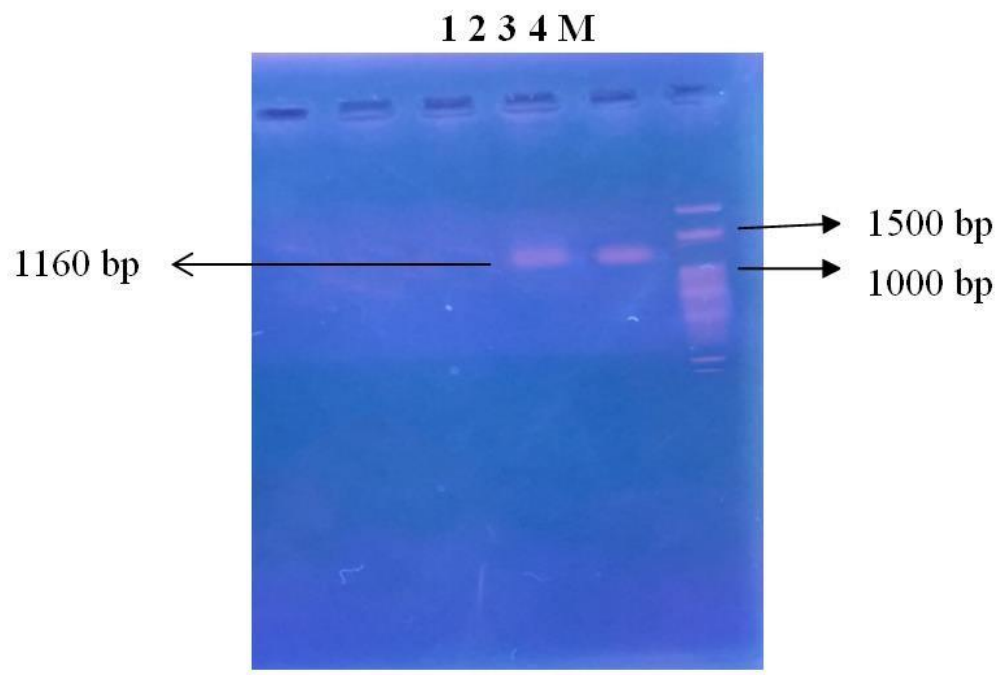

Gambar 7. Visualisasi DNA hasil Amplifikasi dengan PCR (M) : Marker/ penand a. CVPD terdapat pada 1160 bp. Marker diproduksi oleh PT. Genetika Science Indonesia (1) DNA biji tidak bergejala di lapangan(2) DNA tunas tidak bergejala di lapangan (3) DNA biji bergejala di lapangan(4) DNA tunas bergejala di lapangan

\section{SIMPULAN}

Simpulan yang di dapat dari penelitian ini adalah tanaman yang dihasilkan melalui kultur in vitro dari eksplan yang bergejala CVPD, menunjukkan adanya bakteri Liberibacter sehingga tidak dapat di gunakan untuk perbanyakan tanaman jeruk bebas penyakit CVPD. Tanaman yang dihasilkan melalui kultur in vitro dari eksplan yang tidak bergejala CVPD, tidak menunjukkan adanya bakteri Liberibacterasiaticus.

\section{DAFTAR PUSTAKA}

Awuy. 1993. Penampilan Bibit Apomik dan Bibit Seksual Tanaman Jeruk. Zuriat, 4(1):69-74.

Bhojiwani. 1983. Plant Tissue Culture : Theory and Practice. 604 p. New
Delhi:Vikas Publishing House PNT LTD.

Dwiastuti, M.E., A. Triwiratno., A. Supriyanto. 2003. Deteksi Penyebaran Geografis Penyakit CVPD di Bali Utara dengan metode Polymerase Chain Reaction.Jurnal Hortikultura Vol 13, No 2. Hal. 138.

Dwiyani, R. $2015 . \quad$ Kultur JaringanTanaman. Pelawa Sari Denpasar Barat.

Sandrine, J., J. M. Bove, and M. Garnier. 1996. PCR Detection of Two Candidates Liberobacter Spesies Assosiated With Greening Disease of Citrus. MolleculeranCelluler Probes.10: 43-50.

Taylor, G.R. 1993. Polymerase Chain Reaction. Basic Principles and Automation. Dalam PCR A Practical Approach. Editors: J.M Mc Pherson; Quirke and G.R. Taylor. Oxford Universiti Press, New York. 
VLORA VERONICA SIPANGKAR. et al. Kultur Jaringan Jeruk Keprok Tejakula...

Vida, N. 2018. Morfogenesis Batang Bawah Jeruk (Citrus limoniaosbeck) Kultivar Japan scheCitoen pada Kombinasi Media Tumbuh Mengandung Nitrogen. Undergraduate Thesis UIN Sunan Ampel Surabaya. 6 Agustus 2018.

Wijaya, I. N. 2003. Diaphorinacitri KUW (Homoptera : Psyllidae) : Bioteknologi dan Peranannya Sebagai Vektor Penyakit CVPD (Citrus Vein Phloem Degeneration) pada Tanaman Jeruk Siam. (Disertasi) Program Pasca sarjana Institut Pertanian Bogor. 